\title{
An Analysis of Urban Development Potential Based on Ecological Carrying Capacity
}

\author{
Wang, M.M., SHANGHAI TONGJI URBAN PLANNING \& DESIGN INSTITUTE CO.LTD, China
}

\begin{abstract}
Based on ecological carrying capacity and with sustainable development as the purpose, this paper makes a preliminary comprehensive study on the evaluation system of urban development potential based on ecological carrying capacity by establishing the coupling mechanism of ecological carrying capacity and urban development potential.

The specific contents include

1. on the basis of sorting out the research and practice dynamics of ecological carrying capacity and urban development potential, briefly summarises the main problems existing in the current research on ecological carrying capacity and urban development potential, and clarifies that resources and environmental factors are the key components of urban development potential research.

2. By establishing a coupling mechanism linking ecological carrying capacity and urban development potential, this paper examines and analyses the relationship between the two (including external and internal relationships) in terms of concepts, connotations, evaluation methods and indicator systems, and clarifies that ecological carrying capacity is the basis of urban development potential, and that ecological carrying capacity and urban development potential are closely interdependent.

3. The evaluation system of urban development potential based on ecological carrying capacity is constructed from four aspects: resource carrying potential, environmental carrying capacity, human support potential and socio-economic development potential.
\end{abstract}

\section{Keywords}

ecological carrying capacity, urban development potential, relationship, evaluation

\section{Background}

\subsection{Stages of development for a harmonious coexistence between man and nature}

Compared to the long 4.6 billion years of the Earth's existence, human history is only a moment in these 'endless' years (Zhang 2009). However, since the emergence of mankind, the Earth's ecological environment has gradually undergone increasingly significant changes. As society has progressed and the need for human survival and development has grown, human activity has intensified in the transformation of the Earth. Throughout human history, the relationship between humans and nature can be broadly divided into the stages of fearing nature, using nature, conquering nature and harmonising nature, while the development of human beings in an ecological carrying capacity is one of the goals and characteristics of harmonising nature and ecological civilisation. 


\subsection{The need for sustainable development in China}

According to the 1999 China Sustainable Development Strategy Study Report, the first ever compiled by the Sustainable Development Research Group of the Chinese Academy of Sciences, China's sustainable development faces three major pressures and five major "bottlenecks". The three major pressures are population pressure, resource pressure and ecological and environmental pressure. The five "bottlenecks" include: the free separation between population reproduction and material reproduction; the sharp deviation between the production value and ecological value of natural resources; the serious imbalance between the gratuitous appropriation of environmental capacity and the conscious conservation of environmental quality; the unpromising problems of socio-economic efficiency and equality; the institutional failure caused by the externalisation of development costs; and the "green G". Institutional failures and the introduction of "green GDP"

Cities, where the conflict between man and nature is most pronounced, are receiving more and more attention for their sustainable development. How to build sustainable cities is a major issue of urbanisation in the new century. The study of urban development potential covers the prediction of urban development trends and interdisciplinary and synergistic research, and is one of the main directions of research on urban issues. Therefore, this paper takes the ecological carrying capacity as the basis to study the urban development potential in order to decipher the laws of urban development, which will help the ecological construction of cities and provide certain ideas for the construction and management of urban resource use and ecological environment issues.

\section{Concepts and theoretical foundations}

\subsection{Ecological Carrying Capacity}

Carrying capacity is a common concept used in the fields of physics, ecology and statistics. The term carrying capacity comes from ecology and was originally applied to the study of biological populations in natural ecosystems (Gao 2001), and later, in the study of regional systems, it was widely used to characterise the limits of the capacity of a regional resource, environment or ecosystem to withstand local socio-economic development and human activity, becoming one of the most common concepts used to describe constraints on development (Xing 2007). 


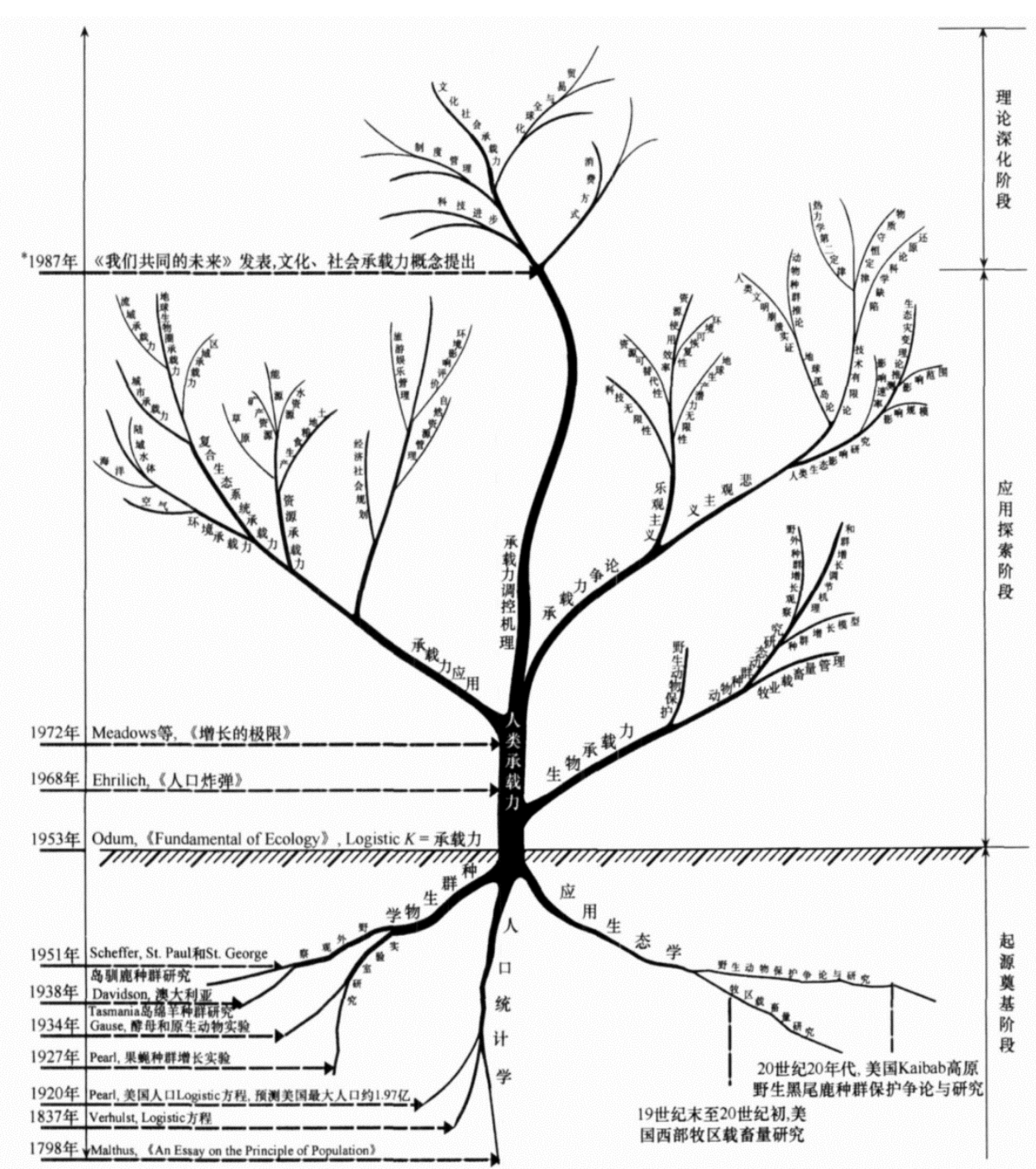

Figure 1. Evolutionary tree of the origins and development of carrying capacity research. Source: Zhang 2009.

Ecological Carrying Capacity (Ecological Carrying Capacity), derived from the concept of carrying capacity (Xu 2005). In the 1970s, due to the shortage of resources and the emergence of environmental pollution and ecological damage, people realised that external disturbances, especially those caused by human activities, exceeded the self-regulating capacity of ecosystems. Some foreign scholars have successively put forward the concepts of Ecological Resilience, Ecological Persistence and Ecological Threshold, while some domestic scholars have put forward the concept of Ecological Carrying Capacity. These concepts are similar in meaning, and they all aim to illustrate the ability of ecosystems to withstand external disturbances, especially those caused by human activities.

According to the discussion of ecological carrying capacity by several scholars, the concept of ecological carrying capacity can be summarised as ecological carrying capacity in a narrow sense and ecological carrying capacity in a broad sense.

(1) Ecological carrying capacity in a narrow sense.

Refers to the self-sustaining and self-regulating capacity of the ecosystem, the capacity of the resource and environmental subsystems to supply and the intensity of socio-economic activities and the number of people with a certain standard of living that they can sustain.

It contains three elements: resource carrying capacity, environmental carrying capacity and ecological resilience. Resource carrying capacity is the basic condition of ecological carrying capacity; environmental 
carrying capacity is the constraint condition of ecological carrying capacity, and ecological resilience is the supporting condition of ecological carrying capacity.

Narrow ecological carrying capacity model: Ecological carrying capacity = pressure / carrying capacity = human social pressure / (resource carrying capacity + environmental carrying capacity + ecological resilience).

(2) Broad ecological carrying capacity.

It refers to the capacity of the regional ecosystem to carry the social scale of population and its corresponding economic methods and total volume in different scale regions within a certain period of time, under the condition of ensuring the rational exploitation and utilization of resources and the virtuous cycle of ecological environment, as well as maintaining a certain scale of material exchange between regions.

The connotation of ecological carrying capacity includes the three subsets of sustainable supply of resources, ecological and environmental pollution absorption and human support role, and ecological carrying capacity consists of three elements: resource carrying capacity, environmental carrying capacity and human support role.

Generalised Ecological Carrying Capacity Model: Ecological carrying capacity = pressure / carrying capacity = human social pressure / (resource carrying capacity + environmental carrying capacity + human support).

Ecological carrying capacity methods include the net first productivity estimation method of natural vegetation, the difference between resources and demand method, the comprehensive evaluation method, the state space method, the ecological footprint method and so on. Among them, the comprehensive evaluation method is to select some development factors and limiting factors as indicators of ecological carrying capacity, compare the detection value of each element with the standard or expectation value to derive the carrying rate of each element, and then derive the comprehensive carrying rate according to the weighting method, which is more comprehensive and flexible in considering factors, and is used in the situation where there are more levels of evaluation indicators, but more information is required.

\subsection{Urban Development Potential}

Development refers to the change of something from small to large, simple to complex, low to high; development, progress; expansion of the size of an organisation, etc.; development is change in a good direction, a reflection of the positive side. Potential is the potential ability and power, the unrealised power or capacity within a subject, or the ability that a subject has but has forgotten to use. Development potential refers to the potential for sustainable development of an object (or system, etc.). Development potential can be interpreted in two ways: qualitatively, in terms of how well an object (or system, etc.) can develop; and quantitatively, in terms of how long an object (or system, etc.) can continue to develop before it begins to deteriorate and die.

Urban Development Potential is a relatively common concept, however, there are few explanations of urban development potential. Urban development potential is a city's intrinsic motivation to grow. It is the ability of a city to sustain its growth at its current level of development, and the best possible future state of development.

There are many methods of evaluating urban development potential, three of the more commonly used methods are: hierarchical analysis, factor analysis and comprehensive evaluation (principal component analysis). 


\section{Analysis of the theoretical relationship between ecological carrying capacity and urban development potential}

Generally speaking, the theoretical relationship (linkage) between ecological carrying capacity and urban development potential can be analysed in two ways.

One is the analysis of the external relationship, which is mainly reflected in the fact that sustainable development is the common exploration objective of ecological carrying capacity and urban development potential, and the ecosystem is the common research object of ecological carrying capacity and urban development potential one has a common objective - sustainable development.

Secondly, the inherent relationship analysis, ecological carrying capacity because of its two-way nature, that is, as far as the role and impact of ecological carrying capacity and urban socio-economic system is concerned, the two systems are influencing and acting on each other. In turn, all aspects of the urban socio-economic system also exert a strong and profound influence and impact on the ecological carrying capacity. This bi-directionality makes ecological carrying capacity an important factor in determining the direction of urban development, and an important factor in influencing the development potential of cities.

\section{Evaluation of urban development potential based on ecological carrying capacity}

\subsection{Evaluation framework}

(1) Evaluation ideas

Ecological carrying capacity evaluation mainly evaluates the ecosystem from three aspects: resource carrying capacity, environmental carrying capacity and human support, among which, resource carrying capacity is the basic condition, environmental carrying capacity is the constraint condition and human support is the influence condition. Starting from the ecological carrying capacity evaluation, the evaluation of urban development potential can also be evaluated through resource carrying capacity, environmental carrying capacity and human support, but these three aspects can hardly reflect the characteristics of urban development potential evaluation. Therefore, economic and social potential is added to this, so that the evaluation of urban development potential consists of four parts: resource carrying potential, environmental carrying potential, human support potential and socio-economic potential. 


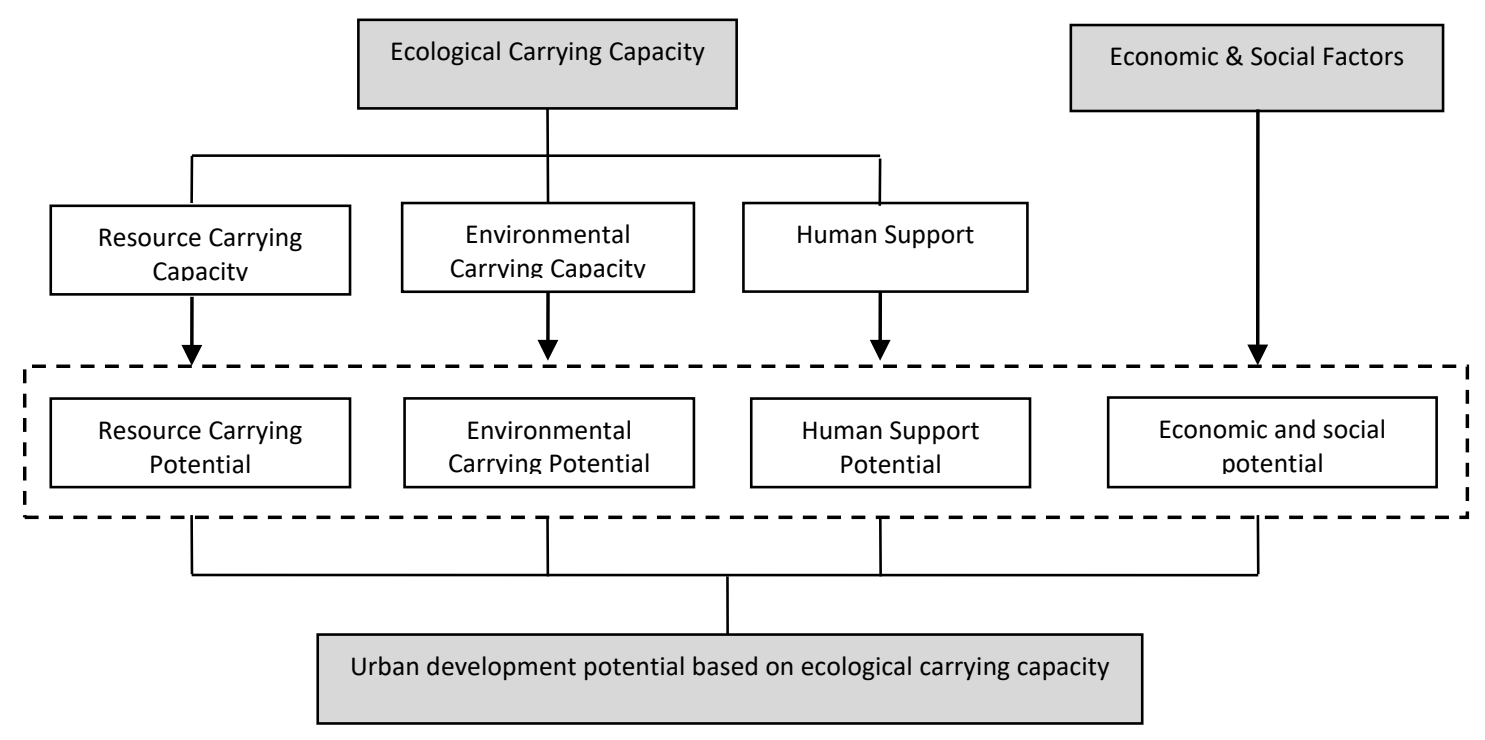

Figure 2:Urban development potential based on ecological carrying capacity. Source: Self-drawn by the author.

\section{(2) Evaluation methodology}

It is proposed to use the integrated evaluation method to conduct a comprehensive evaluation of the urban development potential based on ecological carrying capacity. In simple terms, it is based on the indicator method, in which the scattered indicators are grouped into a corresponding indicator system framework, and the importance and influence of the individual indicators in the whole evaluation system framework is expressed through weighting, thus forming an intuitive and unified evaluation standard. The advantage of the integrated evaluation method is that it maintains the integrity of the entire evaluation framework and creates a quantitative comparison between the individual indicators, thus making it more intuitive.

The specific steps are as follows.

(1) Determine the evaluation objective - evaluation of urban development potential based on ecological carrying capacity.

(2) Analysis of the elements of the evaluation object system. Generally speaking, the evaluation object can be decomposed into several elements, and the composite system is composed of several sub-systems and many elements. The analysis of system elements is to better determine the evaluation factors.

(3) Establish the evaluation index system. The evaluation index system contains the selection of indicators and the establishment of the index model, which is the key link of the evaluation system. Evaluation indicators can be selected in conjunction with the system elements and evaluation purposes, while the establishment of the model depends on the complexity and requirements of the evaluation system.

(4) Collecting data and dimensionless processing of indicator data for different units of measurement. The processed indicators are aggregated to calculate a comprehensive evaluation index or comprehensive evaluation score.

(5) Conduct a comprehensive evaluation. The indexes are aggregated and a comprehensive evaluation index or comprehensive evaluation score is calculated.

(6) The evaluation indexes or scores are used to rank the participants and draw conclusions from them. 
The specific evaluation method is the weighted summation method. The weighted summation method is a widely used method, which is simple and easy to understand, and the process is not too complicated, and is suitable for multi-indicator evaluation systems. In this study, the development potential is evaluated by selecting the factors influencing the development potential, determining the weights of each factor, and then summing the weights to obtain the potential value of the development potential.

The calculation model equation is as follows:

$$
F=\sum_{i=1}^{n} W_{i} Q_{i}
$$

Figure 3: Calculation of model equations. Source: Compiled by the author.

$\mathrm{F}$ is the development potential value, $\mathrm{W}_{\mathrm{i}}$ is the weight of the ith evaluation factor, $\mathrm{Q} \quad \mathrm{i}$ is the quantitative value of the descriptive rating of the ith evaluation factor, and $n$ is the number of evaluation factors $(n=1,2, \ldots .$.$) .$

\subsection{Evaluation indicators}

(1) Methodology for selecting the original indicators

The first is the logical reasoning method, which analyses the various factors influencing the study of urban development potential, and combines them with urban development factors and current national evaluation factors for sustainable urban development, etc. After analysis and synthesis, the indicators of urban development potential are finally launched. The second is the use of mathematical and statistical methods, i.e. data analysis methods borrowed from statistics; take principal component analysis as an example, it is a statistical method of dimensionality reduction, with the help of an orthogonal transformation, the original random vector whose components are related is transformed into a new random vector whose components are not related; using principal component analysis to filter the indicators, the best indicators can be selected from the sub-sets formed by the original indicators to form the best set of indicators. The logical reasoning method is simple and easy to master, but closely related to the professional quality of the researcher, and the results are unpredictable; the mathematical statistical method has a strong scientific basis, but the method is relatively difficult and requires more comprehensive data support from the research object, while the selection of the original set of indicators will have a greater impact on the results. Combined with the above considerations, this study intends to adopt the mathematical and statistical method, and the specific statistical method is determined as the principal component analysis method.

Selection principles: Scientific, Comprehensiveness, Operability, Systematic, Hierarchical.

(2) The original set of indicators

Taking into account the existing urban ecological carrying capacity evaluation indicators, urban development potential evaluation indicators, urban ecosystem health indicators, urban sustainable development indicators, the "Ecological County, Ecological City and Ecological Province Construction Indicators (for trial implementation)" and national garden city standards in China, the original set of indicators for the evaluation of urban development potential based on ecological carrying capacity is shown as follows:

\begin{tabular}{|c|c|l|c|c|c|}
\hline Target layer & Element layer & Indicator layer & Unit & $\begin{array}{c}\text { Standard } \\
\text { value }\end{array}$ & Source \\
\hline $\begin{array}{c}\text { Urban } \\
\text { development } \\
\text { potential }\end{array}$ & $\begin{array}{c}\text { Resource } \\
\text { carrying } \\
\text { potential }\end{array}$ & $\begin{array}{l}\text { Water } \\
\text { resources per } \\
\text { capita }\end{array}$ & $\mathrm{m}^{3} /$ 人 $^{2}$ & - & - \\
\hline
\end{tabular}




\begin{tabular}{|c|c|c|c|c|c|}
\hline \multirow[t]{12}{*}{$\begin{array}{l}\text { based on } \\
\text { ecological } \\
\text { carrying } \\
\text { capacity }\end{array}$} & & $\begin{array}{l}\text { Water } \\
\text { resources } \\
\text { exploitation } \\
\text { rate }\end{array}$ & $\%$ & - & - \\
\hline & & $\begin{array}{l}\text { Arable land } \\
\text { area per } \\
\text { capita }\end{array}$ & Acre/person & - & - \\
\hline & & $\begin{array}{l}\text { Public green } \\
\text { space per } \\
\text { capita }\end{array}$ & $\mathrm{m}^{2} /$ person & $\geq 11$ & $\begin{array}{l}\text { National } \\
\text { Garden City } \\
\text { Indicator, } \\
\text { National } \\
\text { Ecological } \\
\text { City } \\
\text { Indicator }\end{array}$ \\
\hline & & $\begin{array}{l}\text { Proportion of } \\
\text { ecological } \\
\text { land area }\end{array}$ & $\%$ & $\geq 50$ & $\begin{array}{l}\text { National } \\
\text { Eco-City } \\
\text { Indicators }\end{array}$ \\
\hline & & $\begin{array}{l}\text { Forest } \\
\text { vegetation } \\
\text { coverage rate }\end{array}$ & $\%$ & $\begin{array}{l}\text { Mountainous } \\
\text { areas: } \geq 70 \\
\text { Hills: } \geq 40 \\
\text { Plains: } \geq 15 \\
\text { Alpine or } \\
\text { grassland } \\
\text { areas: } \geq 85\end{array}$ & $\begin{array}{l}\text { National } \\
\text { Eco-City } \\
\text { Indicators }\end{array}$ \\
\hline & \multirow{6}{*}{$\begin{array}{c}\text { Environmental } \\
\text { carrying } \\
\text { potential }\end{array}$} & $\begin{array}{l}\text { COD } \\
\text { emissions }\end{array}$ & $\begin{array}{c}\text { kilograms / per } 10000 \\
\text { yuan GDP }\end{array}$ & $<4.0$ & $\begin{array}{l}\text { National } \\
\text { Eco-City } \\
\text { Indicators }\end{array}$ \\
\hline & & $\begin{array}{l}\text { Sulphur } \\
\text { dioxide } \\
\text { emissions }\end{array}$ & $\begin{array}{c}\text { kilograms / per } 10000 \\
\text { yuan GDP }\end{array}$ & $<5.0$ & $\begin{array}{l}\text { National } \\
\text { Eco-City } \\
\text { Indicators }\end{array}$ \\
\hline & & $\begin{array}{l}\text { Annual } \\
\text { emissions of } \\
\text { industrial solid } \\
\text { waste }\end{array}$ & $\mathrm{t}$ & - & - \\
\hline & & $\begin{array}{l}\text { Surface water } \\
\text { quality } \\
\text { compliance } \\
\text { rate }\end{array}$ & $\%$ & $\begin{array}{c}\text { Category } 3 \text { or } \\
\text { above }\end{array}$ & $\begin{array}{l}\text { National } \\
\text { Garden City } \\
\text { Indicators }\end{array}$ \\
\hline & & $\begin{array}{l}\text { Drinking } \\
\text { water source } \\
\text { water quality } \\
\text { compliance } \\
\text { rate }\end{array}$ & $\%$ & 100 & $\begin{array}{l}\text { National } \\
\text { Eco-City } \\
\text { Indicators }\end{array}$ \\
\hline & & $\begin{array}{l}\text { Number of } \\
\text { days with air } \\
\text { environment } \\
\text { quality better } \\
\text { than or equal } \\
\text { to secondary } \\
\text { standard }\end{array}$ & day/year & $\geq 330$ & $\begin{array}{l}\text { National } \\
\text { Eco-City } \\
\text { Indicators }\end{array}$ \\
\hline & $\begin{array}{l}\text { Human } \\
\text { support } \\
\text { potential }\end{array}$ & $\begin{array}{l}\text { Water } \\
\text { consumption } \\
\text { per } 10,000\end{array}$ & $\mathrm{~m}^{3} / \mathrm{RMB} 10,000$ & $\leq 150$ & $\begin{array}{l}\text { National } \\
\text { Eco-City } \\
\text { Indicators }\end{array}$ \\
\hline
\end{tabular}




\begin{tabular}{|c|c|c|c|c|}
\hline & Yuan GDP & & & \\
\hline & $\begin{array}{l}\text { Energy } \\
\text { consumption } \\
\text { per } 10,000 \\
\text { Yuan GDP }\end{array}$ & $\begin{array}{l}\text { Tonnes of standard } \\
\text { coal / RMB 10,000 }\end{array}$ & $\leq 0.9$ & $\begin{array}{l}\text { National } \\
\text { Eco-City } \\
\text { Indicators }\end{array}$ \\
\hline & $\begin{array}{l}\text { Industrial } \\
\text { waste gas } \\
\text { treatment } \\
\text { rate }\end{array}$ & $\%$ & 100 & $\begin{array}{l}\text { Metropolitan } \\
\text { Experience } \\
\text { Value }\end{array}$ \\
\hline & $\begin{array}{l}\text { Industrial } \\
\text { wastewater } \\
\text { discharge rate } \\
\text { to standard }\end{array}$ & $\%$ & 100 & $\begin{array}{l}\text { Metropolitan } \\
\text { Experience } \\
\text { Value }\end{array}$ \\
\hline & $\begin{array}{l}\text { Centralized } \\
\text { treatment } \\
\text { rate of } \\
\text { domestic } \\
\text { sewage }\end{array}$ & $\%$ & $\geq 70$ & $\begin{array}{l}\text { National } \\
\text { Eco-City } \\
\text { Indicators }\end{array}$ \\
\hline & $\begin{array}{l}\text { Harmless } \\
\text { treatment } \\
\text { rate of } \\
\text { domestic } \\
\text { waste } \\
\end{array}$ & $\%$ & $\geq 90$ & $\begin{array}{l}\text { National } \\
\text { Eco-City } \\
\text { Indicators }\end{array}$ \\
\hline & $\begin{array}{l}\text { Industrial solid } \\
\text { waste disposal } \\
\text { utilization rate }\end{array}$ & $\%$ & $\geq 90$ & $\begin{array}{l}\text { National } \\
\text { Eco-City } \\
\text { Indicators }\end{array}$ \\
\hline & $\begin{array}{l}\text { Industrial } \\
\text { water reuse } \\
\text { rate }\end{array}$ & $\%$ & $\geq 80$ & $\begin{array}{l}\text { National } \\
\text { Eco-City } \\
\text { Indicators }\end{array}$ \\
\hline & $\begin{array}{l}\text { Share of } \\
\text { environmental } \\
\text { industries in } \\
\text { GDP }\end{array}$ & $\%$ & 3.5 & $\begin{array}{l}\text { National } \\
\text { Eco-City } \\
\text { Indicators }\end{array}$ \\
\hline \multirow{6}{*}{$\begin{array}{c}\text { Socio- } \\
\text { economic } \\
\text { development } \\
\text { potential }\end{array}$} & $\begin{array}{l}\text { Economic } \\
\text { density of } \\
\text { built-up areas }\end{array}$ & $\mathrm{RMB} 10,000 / \mathrm{km}^{2}$ & - & 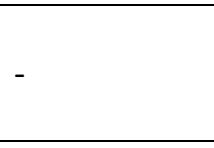 \\
\hline & $\begin{array}{l}\text { Engel } \\
\text { Coefficient }\end{array}$ & $\%$ & $\leq 40$ & $\begin{array}{l}\text { Metropolitan } \\
\text { Experience } \\
\text { Value }\end{array}$ \\
\hline & $\begin{array}{l}\text { Urban-rural } \\
\text { income gap }\end{array}$ & - & $\leq 3.3$ & $\begin{array}{l}\text { Metropolitan } \\
\text { Experience } \\
\text { Value }\end{array}$ \\
\hline & $\begin{array}{l}\text { Tertiary } \\
\text { Education } \\
\text { Enrolment }\end{array}$ & $\%$ & $\geq 30$ & $\begin{array}{l}\text { Metropolitan } \\
\text { Experience } \\
\text { Value }\end{array}$ \\
\hline & $\begin{array}{l}\text { Transport } \\
\text { density in the } \\
\text { territory }\end{array}$ & $\mathrm{km} / \mathrm{km}^{2}$ & - & - \\
\hline & $\begin{array}{l}\text { Number of } \\
\text { telephone } \\
\text { households } \\
\text { per } 1,000\end{array}$ & Households/thousands & - & - \\
\hline
\end{tabular}




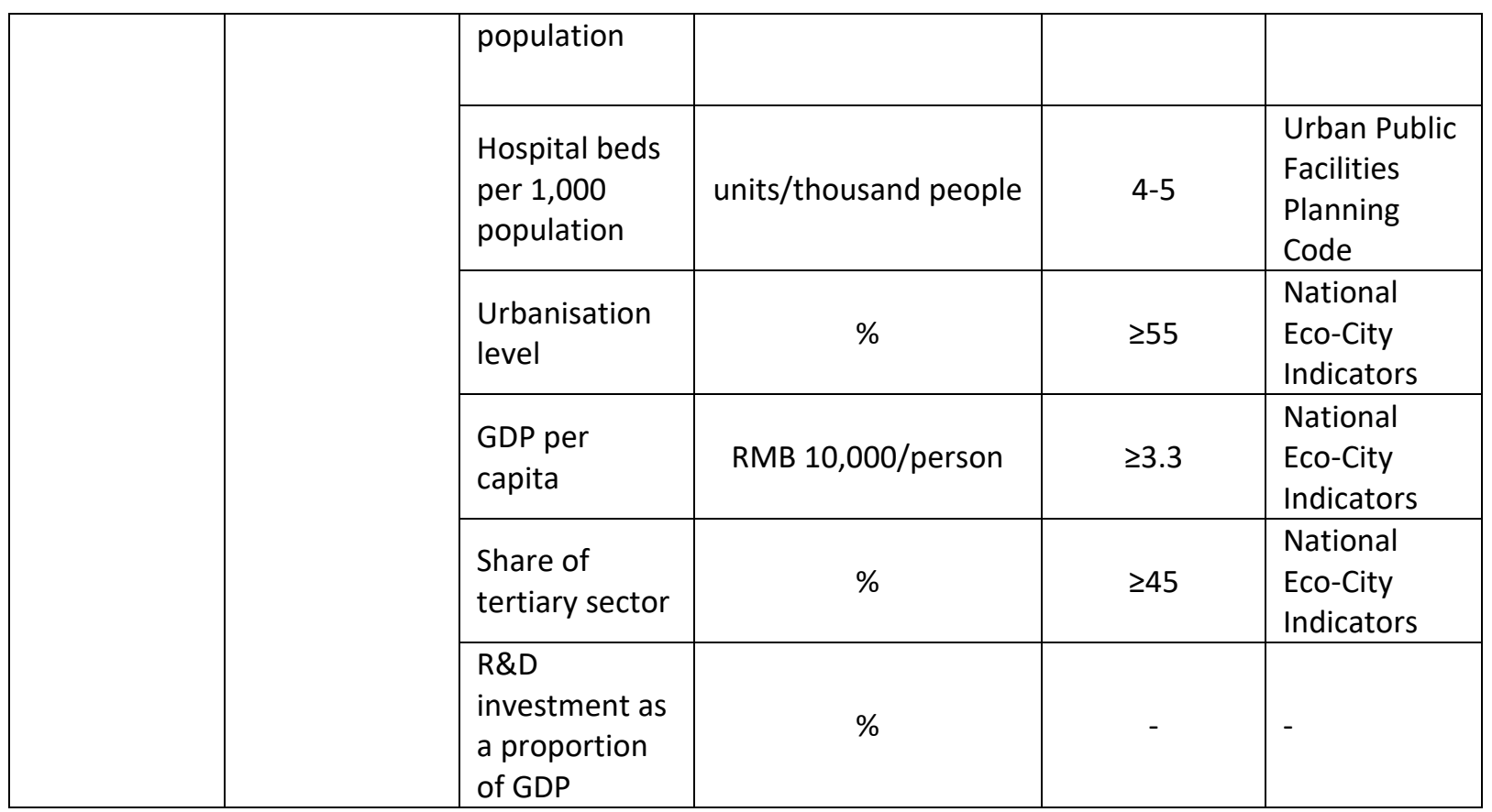

Figure 4: Original set of indicators for evaluating urban development potential based on ecological carrying capacity. Source: Compiled by the author

(3) Indicator selection

Indicators were screened using principal component analysis.

Assume that there are $n$ geographical samples, each with a total of $p$ variables, forming a geographical data matrix of order $n \times p$, as follows.

$$
X=\left[\begin{array}{cccc}
x_{11} & x_{12} & \cdots & x_{1 p} \\
x_{21} & x_{22} & \cdots & x_{2 p} \\
\vdots & \vdots & \vdots & \vdots \\
x_{n 1} & x_{n 2} & \cdots & x_{n p}
\end{array}\right]
$$

Figure 5: Matrix formula. Source: Compiled by the author from publicly available information

When $\mathrm{p}$ is large, it is more problematic to examine the problem in a p-dimensional space. To overcome this difficulty, it is necessary to perform a dimensionality reduction process, i.e. to replace the original more variable indicators with a smaller number of composite indicators, and to make these fewer composite indicators reflect as much information as possible that is reflected in the original more variable indicators, while at the same time they are independent of each other.

Definition: $x_{1}, x_{2}, \ldots, \quad x_{p}$ are the original variable indicator, $z 1, z 2, \ldots, z m(m \leq p)$ are the new variable indicator, as follow.

$$
\left\{\begin{array}{c}
z_{1}=l_{11} x_{1}+l_{12} x_{2}+\cdots+l_{1 p} x_{p} \\
z_{2}=l_{21} x_{1}+l_{22} x_{2}+\cdots+l_{2 p} x_{p} \\
\vdots \\
z_{m}=l_{m 1} x_{1}+l_{m 2} x_{2}+\cdots+l_{m p} x_{p}
\end{array}\right.
$$

Figure 6: Equation. Source: Compiled by the author from publicly available information.

The principle of determining the coefficient $l_{\mathrm{ij}}$ : 
(1) $z_{i}$ and $z_{j}(i \neq j ; i, j=1,2, \ldots, m)$ are mutually independent.

(2) $z_{1}$ is the largest variance of all linear combinations of $x_{1}, x_{2}, \ldots, x_{p}$, and $z_{2}$ is the largest variance of all linear combinations of $\mathrm{x}_{1}, \mathrm{x}_{2}, \ldots, \mathrm{x}_{\mathrm{p}}$ that are not correlated with $\mathrm{z}_{1}$.

The essence of principal component analysis is to determine the loadings $\mathrm{I}_{\mathrm{ij}}(\mathrm{i}=1,2, \ldots, m ; \mathrm{j}=1,2, \ldots, p)$ of the original variable $x_{j}(j=1,2, \ldots, p)$ on the plural principal components $z_{i}(i=1,2, \ldots, m)$.

(4) Construction of the index system

After the principal component analysis of the original indicators, the urban development potential evaluation index system based on ecological carrying capacity is constructed by combining the analysis results and the actual situation of the research object.

Due to the complexity of the principal component analysis operations, computer calculations can usually be carried out with the help of software such as SPSS to produce the required results.

\subsection{Weighting of evaluation indicators}

The weighting of the indicators of the evaluation index system is one of the keys to the correctness and scientificity of the comprehensive evaluation. Generally speaking, the commonly used methods to determine the weights are expert scoring method and hierarchical analysis method. Expert scoring method is based on experts' theoretical knowledge and practical experience to determine the weights, although the accuracy of the weights is difficult to test, but the operation is convenient; hierarchical analysis (AHP method) and principal component analysis are mathematical methods, which require special mathematical modelling software (such as SPSS, yahhp, etc.) to calculate, among which principal component analysis, as a more scientific and operable method, has a stronger persuasive power of the results. This thematic study intends to use principal component analysis to perform operations on the required weights.

\subsection{Implementing the evaluation}

After the indicators and weights have been determined, the evaluation results of the objects can be derived using the multi-factor weighted summation method. The results can be ranked according to the evaluation results, the causes of the results of different objects can be analysed and corresponding measures to improve the development potential of the city can be proposed.

\section{Conclusion}

Supported by ecology and urbanism theories and based on ecological carrying capacity research, this paper constructs a theory and method of urban development potential based on ecological carrying capacity, and learns that: ecological carrying capacity is an important factor affecting urban development potential; evaluation of urban development potential should include four aspects: resource carrying potential, environmental carrying potential, human support potential and socio-economic development potential; ecological carrying capacity and urban The combined study of ecological carrying capacity and urban development potential has a stronger guiding significance for urban development; urban development potential has time attributes.

Finally, the research on ecological carrying capacity and urban development potential is still inadequate in a number of aspects, and needs to be updated and improved in the light of various cases. 


\section{References}

China General Environmental Monitoring Station. (2004) Research on the evaluation of ecological environment quality in China, 1st edn. Beijing: China Environmental Science Press.

Cuadra, M., Bjorklund, J. (2007) 'Assessment of economic and ecological carrying capacity of agricultural crops in Nicaragua', Ecological Indicator, 6(7), p133-149.

Du, Z.W., Zhang, H.G. and Ye, Y.Y. (2019) 'Urban shrinkage and growth: Measurement and determinants of economic resilience in the Pearl River Delta', Journal of Geographical Sciences, 29(8). p13311345 .

Ewing, B.R., Hawkins, T.R. and Wiedmann, T.O. et al.(2012) 'Integrating ecological and water footprint accounting in a multi-regional input-output framework', Ecological Indicators, 23(4), p1-8.

Gao, J.X. (2001) Exploration of Sustainable Development Theory - Theory, Methodology and Application of Ecological Carrying Capacity. 1st edn. Beijing: China Environmental Sustainability Press.

Haberl, H., Erb, K-H. and Krausmann, F.(2014) 'Human Appropriation of Net Primary Production: Patterns, Trends, and Planetary Boundaries', Annual Review of Environment and Resources, 39(8), p363391.

Lein, J.K.(2010) 'Mapping environmental carrying capacity using an artificial neural network: A first experiment', Land Degradation \& Development, 6(1), p17-28.

Roldan, M. (2006) 'Immigration and the environment: Underlying values and scope of analysis', Ecological Economics, 59(2), p208-213.

Siche, R., Pereira, L. and Agostinho, F. et al.(2010) 'Convergence of ecological footprint and emergy analysis as a sustainability indicator of countries: Peru as case study', Communications in Nonlinear Science and Numerical Simulation, 15(10) , p3182-3192.

Sustainable Development Research Group of the Chinese Academy of Sciences, (1999) 1999 China Sustainable Development Strategy Report. 1st edn. Beijing: Science Press.

Vetter, S., Bond, W. J.(2012) 'Changing predictors of spatial and temporal variability in stocking rates in a severely degraded communal rangeland' Land Degradation \& Development, 23(2), p190-199.

Wang, J. et al. (2005) 'Advances in environmental carrying capacity research', Journal of Applied Ecology, 16(4), p768-772.

Wang, K.Y. (2007) Ecological carrying capacity composite model system and application, 1st edn. Beijing: Science Press.

Wang, S.J., Cui, Z.T. and Lin, J.J. et al. (2021) 'Coupling and Coordination of Urbanisation and Ecological Resilience in the Pearl River Delta Region', Acta Geographica Sinica, 76(4), p973-991.

Xie, W.X., Huang, Q.X and He, C.Y.(2017) 'The relationship between urban expansion patterns and ecological footprint in Shandong Peninsula', Acta Ecologica Sinica, 37( 3) , p969-978.

Xing, Y.Q., FENG, J.C. and Dou, M. (2007) Theory and practice of regional ecological environment carrying capacity. 1st edn. Beijing: Geological Publishing House.

Xu, L.W., Yang, Z.F. and Li, W. (2005) 'Theory and evaluation methods for the carrying capacity of urban ecosystems', Acta Ecologica Sinca, 25(4), p771-777. 
Xu, Z.M., Cheng, G.D. and Zhang, Z.Q. (2001) 'Ecological footprint approach - a new method for quantitative sustainability research - an example of ecological footprint calculation in Zhangye region in 1995', Acta Ecologica Sinca, 21(9), p1485-1494.

Zhang, L.B. (2009) Research on the theory and method of ecological carrying capacity of cities--Shenzhen as an example. 1st edn. Beijing: China Environmental Science Press.

Zhang, L.B., Li, W.H. and Liu, X.F. et al. (2009) 'Origins, development and prospects of carrying capacity theory', Acta Ecologica Sinca, 29(2), p878-888.

Zhao, D.S., Guo, C.Y. and Zheng, D. et al.(2019) 'Review of ecological carrying capacity', Acta Ecologica Sinica, 39(2), p399-410 . 